\title{
Kidney effects in long term exposed lead smelter
} workers

\author{
L Gerhardsson, D R Chettle, V Englyst, G F Nordberg, H Nyhlin, M C Scott, A C Todd, \\ O Vesterberg
}

\begin{abstract}
Occupational exposure to lead may cause kidney damage. This study was carried out on a cohort of 70 active and 30 retired long term exposed lead smelter workers. Their kidney function was compared with 31 active and 10 retired truck assembly workers who had no occupational exposure to lead. The lead workers had been regularly followed up with measurements of lead concentration in blood since 1950. Previous exposure to lead was calculated as a time integrated blood lead index for each worker. Blood and urine samples were obtained from all subjects. The concentration of lead in blood (B-Pb) and urine (U-Pb) was analysed. The urinary concentrations of several sensitive indicators of early tubular (U- $\boldsymbol{\beta}_{2}-$ microglobulin (U- $\left.\boldsymbol{\beta}_{2}-\mathbf{m}\right)$; U-N-acetyl- $\boldsymbol{\beta}$ glucosaminidase (U-NAG)) and glomerular kidney damage (U-albumin) were determined. The B-Pb and U-Pb values were significantly higher among active and retired lead workers compared with their corresponding control groups. The highest concentrations were found among the active lead workers. The concentrations of the parameters of kidney function investigated were of the same magnitude for exposed workers and controls. No clinical
\end{abstract}

Department of Environmental Medicine, University of Umeå, S-901 87 Umeå, Sweden

L Gerhardsson, G F Nordberg

Department of Occupational and Environmental Medicine, Lund University, S-221 85 Lund, Sweden

L Gerhardsson

Medical Physics Group, School of Physics and Space Research, University of Birmingham, Birmingham B15 2TT, UK

D R Chettle, M C Scott, A C Todd

The Company Health Service, Boliden Mineral AB, S-932 00 Skelleftehamn, Sweden

V Englyst

The Company Health Service, Volvo Lastvagnar AB, Umeverken, S-901 24 Umeå, Sweden

$\mathrm{H}$ Nyhlin

Division of Medical Chemistry, National Institute of Occupational Health, S-171 84 Solna, Sweden

O Vesterberg signs of renal impairment were found among the workers. No correlations of clinical importance existed between concentrations of $U$-albumin, $U-\beta_{i}-m$, and $U=N A G$ activity on the one hand and the concentrations of $\mathrm{B}-\mathrm{Pb}$, cumulative blood lead index, $U-P b$, and lead concentrations in the calcaneus and tibia on the other, among lead workers and controls. Despite many years of moderate to heavy exposure to lead, particularly for the retired lead workers, no signs of adverse effects on the kidney such as early tubular or glomerular malfunction were found. Reversible changes in kidney function during the 1950 s and 1960 s could not be excluded, however, due to a greater exposure to lead during that time.

Inorganic lead is widely distributed. As well as exposure from the general environment, exposure to lead may occur in lead mines, lead smelting and refining operations, storage battery factories, brass foundries, and glass works. In the working environment exposure may occur both through inhalation and through ingestion of contaminated food, drinks, and snuff.

The Rönnskär smelter in the northern part of Sweden has specialised in the processing of complex and contaminated raw materials. In addition to the main products of copper and lead, the company, Boliden Mineral AB, operates plants for the recovery of precious metals, special products, and sulphur products from the raw materials. The processes have mostly been developed within the company.

In the production of lead, the smelter primarily uses lead concentrates from the company, and also flue dust containing lead obtained as a byproduct from the company's plant for the production of copper and zinc concentrates. Flash smelting is used for the production of lead. The concentrate is smelted in an electric furnace without previous roasting or sintering, and the furnace lead is then converted and refined. Lead production at the smelter varies between 40000 and 70000 tonnes a year. Many employees start work at the smelter between the ages of 20 and 30 and continue their work up to retirement. A duration of employment of 30 to 40 years is therefore not unusual. 
Absorbed lead is excreted from the body mainly through the urine and the faeces. The excretion into urine is mostly through glomerular filtration as indicated by experimental animal studies. ${ }^{1}$

Inorganic lead can affect the human body in several ways. The exposure may disturb haeme synthesis, erythrocyte survival, the nervous system, the gastrointestinal tract, reproduction, and possibly also the cardiovascular system. ${ }^{2}$

Lead may also cause kidney damage..$^{2-4}$ Interstitial nephritis, tubular damage, and at a late stage of the disease, glomerular damage, have also been reported. ${ }^{35}$ Functionally, these effects on the kidney may cause leakage of enzymes from tubular cells and excretion of low and high molecular weight proteins into the urine.

Hypertension is a well recognised risk factor in the progression of renal failure. Exposure to lead has been associated with hypertension ${ }^{67}$ even with only modest increases in blood lead concentrations. ${ }^{8-10}$ Toxicological studies have also documented an association between increased absorption of lead and hypertension. ${ }^{11}$ The effects of lead appear to be mediated through toxic effects on the kidneys and by direct action on vascular smooth muscle. ${ }^{4}$ Lead can inhibit renal tubular reabsorption of sodium directly, probably by acting on $\mathrm{Na}^{+} / \mathrm{K}^{+}$ATPase to alter intracellular concentrations of sodium and calcium ions. A change in cellular volume may raise plasma renin activity. Lead may also affect cytosolic free calcium ion concentration in juxtaglomerular cells. Finally, lead may alter renal vascular reactivity to $\alpha$-adrenergic agents. ${ }^{12}$

In this study sensitive indicators of early tubular or glomerular damage to the kidney have been analysed in long term exposed lead smelter workers. Due to the unique records of blood lead (B-Pb) concentrations collected at the smelter since 1950, it has been possible to relate the findings on kidney function in each worker to his previous exposure to lead.

\section{Material and methods}

Seventy active and 30 retired long term exposed lead smelter workers participated in our study. Their kidney function was compared with a group of 31 active and 10 retired truck assembly workers with no occupational exposure to lead. The truck assembly plant is situated in the city of Umea some 140 kilometers from the smelter.

Blood and urine samples were obtained from all subjects. The urine sampling period was about four hours. After collection, the urine was immediately checked with dipsticks (Ecur-4-test; Boehringer Mannheim, Germany) for signs of albumin, glucose, erythrocytes, and leucocytes, and the $\mathrm{pH}$ was determined. The samples were then immediately put into a freezing room. After transportation in a deep frozen state, the urinary concentrations of $\beta_{2}$ - microglobulin ( $\left.\mathrm{U}-\beta_{2}-\mathrm{m}\right)$, albumin, and the tubular enzyme $\mathrm{N}$-acetyl- $\beta$-glucosaminidase (U-NAG) were analysed at the Department of Medical Chemistry, National Institute of Occupational Health, Solna, Sweden.

Urinary $\beta_{2}$-microglobulin concentration was analysed by radioimmunoassay (RIA; Pharmacia, Uppsala, Sweden). Only urine samples with a $\mathrm{pH}$ higher than 5.5 were used for the determinations, as a time and temperature dependent degradation of $\mathrm{U}-\beta_{2}$-m occurs when the urinary $\mathrm{pH}$ is less than $5 \cdot 5 .{ }^{13}$

U-Albumin concentration was determined by zone immunoelectrophoresis assay. ${ }^{14}$ The standard curve was prepared by diluting Seronorm (Nycomed, Oslo, Norway) in the electrophoresis buffer. Samples of $10 \mu \mathrm{l}$ were analysed in duplicate. Mostly the results showed a good agreement between each pair of values. The accuracy of the method for U-albumin determination was checked and scored well in interlaboratory comparisons organised in the European Community by a laboratory in Amsterdam, as well as in a study organised by Centers for Disease Control in Atlanta, USA. The quality control programme also included low concentrations in the normal range.

Urinary $\mathrm{N}$-acetyl- $\beta$-glucosaminidase activity was measured after gel filtration of the urine samples on Sephadex G50 (Pharmacia) to remove interference. The assay was carried out with a kit and recommendations from Boehringer Mannheim, Germany. ${ }^{15}$ The U-NAG analyses showed good agreement with results obtained by The Amsterdam Laboratory.

The values of the urinary parameters were adjusted for dilution by the concentrations of creatinine in urine.

Lead concentrations in venous blood and urine samples were determined in duplicate at the company's research laboratory by atomic absorption spectrophotometry (AAS) with a Perkin Elmer 5000-Z combined with HGA-500 (standards (B901, B902, U108) from Nycomed, Oslo, Norway). The analyses of blood lead at the smelter started in 1950 . Emission spectrometry was used for the analyses during the period 1950-69. This method was replaced by AAS in $1967 . .^{16}$ The accumulated exposure to lead since 1950 was calculated as a cumulative blood lead index by a summation of the annual mean blood lead concentrations for each worker expressed in $\mu \mathrm{mol} / 1$.

During the 1950s and the 1960s the research laboratory exchanged blood samplès for lead determination with laboratories in West Germany and the United Kingdom. ${ }^{17}{ }^{18}$ Since the 1970s, the laboratory has participated in a national quality control programme organised by the National Board of Occupational Health and Safety in Stockholm, Sweden ${ }^{14-22}$ and the results have always been in good agreement with the expected concentrations. 
Many other parameters were also analysed in the blood samples-for example, plasma (P)-creatinine and haemoglobin concentrations, sedimentation rate, and red and white cell counts. These analyses, together with determination of the creatinine concentration in urine (U-creatinine) were performed at the department of clinical chemistry, University Hospital of Umeå and monitored by routine quality control procedures.

The lead concentrations in the calcaneus and tibia of all participants were analysed by $x$ ray fluorescence. The method has been described in detail elsewhere. ${ }^{23-26}$

An occupational and medical history regarding working sites at the smelter, alcohol consumption, smoking habits, food intake, and hobbies involving lead was obtained from each worker, and a control was matched by the use of a computerised questionnaire. A physical examination of all subjects was also made.

\section{STATISTICS}

As group sizes and variances differed considerably between the groups, non-parametric statistical methods-for example, Kruskal-Wallis one way analysis of variance, Mann-Whitney $U$ test, and Spearman rank order correlation coefficients-were used. $p$ Values less than 0.05 (Mann-Whitney two tailed tests) were considered statistically significant.

Table 1 Mean (SD) values for age, time of employment, and duration of retirement in smelter workers and referents

\begin{tabular}{lll}
\hline & Exposed workers & Referents \\
\hline Mean age (y) & & \\
$\quad$ Active workers & $37 \cdot 4(12 \cdot 6)$ & $43 \cdot 2(13 \cdot 0)$ \\
$\quad$ Retired workers & $67 \cdot 9(4 \cdot 7)$ & $69 \cdot 5(3 \cdot 2)$ \\
Employment time $(y)$ & $14 \cdot 3(9 \cdot 7)$ & $16 \cdot 4(8 \cdot 3)$ \\
$\quad$ Active workers & $32 \cdot 6(6 \cdot 3)$ & $20 \cdot 0(9 \cdot 6)$ \\
$\quad$ Retired workers & $7 \cdot 4(4 \cdot 8)$ & $5 \cdot 1(2 \cdot 6)$ \\
Duration of retirement $(y)$ & \\
$\quad$ Retired workers &
\end{tabular}

\section{Results}

Table 1 presents the mean values for age, duration of employment, and period of retirement of exposed lead workers and controls. When compared with the active control group, active lead workers were significantly younger $(p=0.036)$. Retired lead workers had a significantly longer duration of employment than the retired truck assembly workers $(p=0.001)$. No differences were found in other variables between exposed workers and their corresponding controls.

Table 2 presents median values and ranges of $\mathrm{B}-\mathrm{Pb}$ concentrations, cumulative blood lead index, and lead concentrations in the calcaneus and tibia. The lead concentrations in bone in active and retired lead workers were significantly higher $(p<0.001)$ than in their corresponding control groups. The retired smelter workers had the highest values.

Table 3 gives the median values and ranges of $\mathrm{U}-\mathrm{Pb}, \mathrm{U}$-albumin, and $\mathrm{U}-\beta_{2}-\mathrm{m}$ concentrations and U-NAG activity. Table 4 presents the median values and ranges for $\mathrm{P}$-creatinine concentration, creatinine clearance, albumin clearance, relative albumin clearance (U-albumin $\times$ P-creatinine/S-albumin $\times$ U-creatinine), $\beta_{2}-\mathrm{m}$ clearance, and relative $\beta_{2}-\mathrm{m}$ clearance $\left(\mathrm{U}-\beta_{2}-\mathrm{m} \times \mathrm{P}\right.$-creatinine/serum- $\beta_{2}-\mathrm{m} \times$ U-creatinine).

The $\mathrm{B}-\mathrm{Pb}$ and $\mathrm{U}-\mathrm{Pb}$ values were significantly higher among active and retired lead workers compared with their corresponding control groups ( $p$ $<0.001)$. As expected the highest concentrations were found among the active lead workers. The concentrations of $\mathrm{U}$-albumin and $\mathrm{U}-\beta_{2}-\mathrm{m}$ and U-NAG activity among lead workers and controls were within the normal reported ranges. The concentrations of the urinary glomerular (U-albumin, albumin clearance, relative albumin clearance) and tubular ( $\mathrm{U}-\beta_{2}-\mathrm{m}$ concentration, U-NAG activity, $\beta_{2}-\mathrm{m}$ clearance, relative $\beta_{2}-\mathrm{m}$ clearance) function parameters investigated were of the same magnitude for exposed workers and controls. Accordingly, no signs of clinical renal impairment were found among the workers.

Table 2 Blood lead concentration, cumulative blood lead index, and lead concentrations in calcaneus and tibia in smelter workers and referents

\begin{tabular}{|c|c|c|c|c|}
\hline & \multicolumn{2}{|c|}{ Exposed workers } & \multicolumn{2}{|c|}{ Referents } \\
\hline & Median & Range & Median & Range \\
\hline $\begin{array}{l}\text { B-Pb }(\mu \mathrm{mol} / \mathrm{l}): \\
\text { Active workers } \\
\text { Retired workers }\end{array}$ & $\begin{array}{l}1.54 \\
0.48\end{array}$ & $\begin{array}{l}0.24 \text { to } 2.29 \\
0.16 \text { to } 1.01\end{array}$ & $\begin{array}{l}0 \cdot 20 \\
0 \cdot 17\end{array}$ & $\begin{array}{l}0.08 \text { to } 0.60 \\
0.11 \text { to } 0.59\end{array}$ \\
\hline $\begin{array}{l}\text { Cumulative blood lead index }(\mu \mathrm{mol} / \mathrm{l}) \text { : } \\
\text { Active workers } \\
\text { Retired workers }\end{array}$ & $\begin{array}{r}17 \cdot 85 \\
72 \cdot 20\end{array}$ & $\begin{array}{l}3 \cdot 30 \text { to } 104 \cdot 20 \\
21 \cdot 30 \text { to } 98 \cdot 20\end{array}$ & & \\
\hline $\begin{array}{l}\text { Lead concentrations in calcaneus }(\mu \mathrm{g} / \mathrm{g} \text { bone mineral): } \\
\text { Active workers } \\
\text { Retired workers }\end{array}$ & $\begin{array}{r}48 \cdot 6 \\
100 \cdot 2\end{array}$ & $\begin{array}{r}0 \cdot 4 \text { to } 217 \cdot 8 \\
34 \cdot 8 \text { to } 188 \cdot 9\end{array}$ & $\begin{array}{l}12 \cdot 2 \\
30 \cdot 2\end{array}$ & $\begin{array}{r}-12 \cdot 7 \text { to } 43 \cdot 0 \\
-7 \cdot 1 \text { to } 56 \cdot 7\end{array}$ \\
\hline $\begin{array}{l}\text { Active workers } \\
\text { Retired workers }\end{array}$ & $\begin{array}{l}13 \cdot 0 \\
39 \cdot 3\end{array}$ & $\begin{array}{r}-4 \cdot 1 \text { to } 72 \cdot 8 \\
2.9 \text { to } 73 \cdot 4\end{array}$ & $\begin{array}{r}3 \cdot 4 \\
12 \cdot 0\end{array}$ & $\begin{array}{l}-9.4 \text { to } 13 \cdot 3 \\
-6.7 \text { to } 23.7\end{array}$ \\
\hline
\end{tabular}


Table 3 Urinary lead, $U$-albumin, and $U-\beta_{2}-m$ concentration, and $U-N A G$ activity in smelter workers and referents

\begin{tabular}{|c|c|c|c|c|}
\hline & \multicolumn{2}{|c|}{ Exposed workers } & \multicolumn{2}{|l|}{ Referents } \\
\hline & Median & Range & Median & Range \\
\hline \multicolumn{5}{|l|}{$\mathrm{U}-\mathrm{Pb}(\mu \mathrm{g} / \mathrm{mmol}$ creatinine $)$ : } \\
\hline Active workers & $3 \cdot 78$ & 1.22 to 13.57 & 0.39 & 0.06 to 1.63 \\
\hline \multicolumn{5}{|l|}{$\mathrm{U}$-albumin ( $\mathrm{mg} / \mathrm{mmol}$ creatinine): } \\
\hline $\begin{array}{l}\text { Active workers } \\
\text {. }\end{array}$ & 0.67 & 0.14 to 8.56 & 1.08 & 0.13 to 6.78 \\
\hline Retired workers & 1.68 & 0.40 to 9.38 & 1.89 & 0.33 to 9.33 \\
\hline \multicolumn{5}{|l|}{$\mathrm{U}-\beta_{2}-\mathrm{m}$ (mg/mmol creatinine): } \\
\hline Active workers & 0.010 & 0.002 to 0.213 & 0.010 & 0.003 to 0.100 \\
\hline $\begin{array}{l}\text { Retired workers } \\
\text { U-NAG }(\mathrm{U} / \mathrm{mmol} \text { creatinine })\end{array}$ & 0.019 & 0.004 to 0.250 & 0.012 & 0.004 to 0.100 \\
\hline \multicolumn{5}{|l|}{ U-NAG (U/mmol creatinine): } \\
\hline $\begin{array}{l}\text { Active workers } \\
\text { Retired workers }\end{array}$ & $\begin{array}{l}0 \cdot 13 \\
0 \cdot 23\end{array}$ & $\begin{array}{l}0.02 \text { to } 0.58 \\
0.02 \text { to } 1.15\end{array}$ & $\begin{array}{l}0 \cdot 22 \\
0 \cdot 29\end{array}$ & $\begin{array}{l}0.02 \text { to } 0.69 \\
0.08 \text { to } 0.73\end{array}$ \\
\hline
\end{tabular}

Table $4 P$-creatinine concentration, creatinine clearance, albumin clearance, relative albumin clearance, $\beta_{2}-m$ clearance and relative $\beta_{2}-m$ clearance in smelter workers and referents

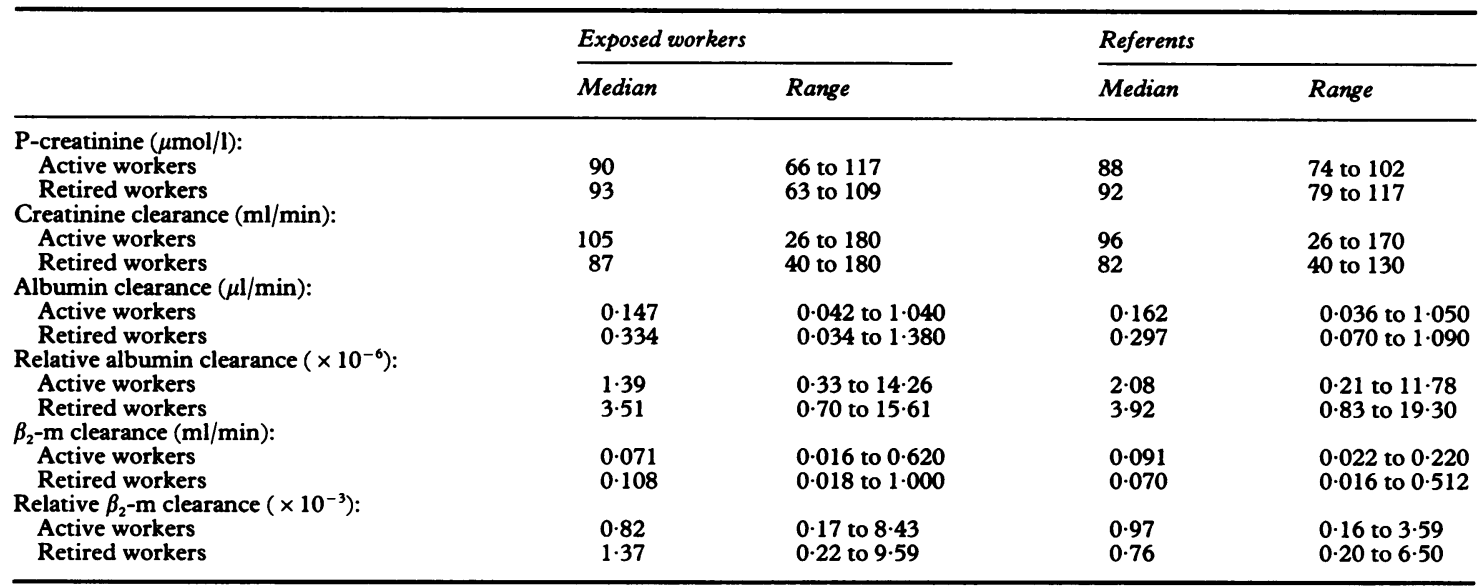

For active lead workers, $\mathrm{U}-\boldsymbol{\beta}_{2}-\mathrm{m}$ concentration was positively correlated with both $\mathrm{B}-\mathrm{Pb}(\mathrm{r}=0 \cdot 27$; $\mathrm{p}=0.022)$ and $\mathrm{U}-\mathrm{Pb}$ concentrations $(\mathrm{r}=0.39$; $\mathrm{p}=0.001$ ). A positive correlation was also found between U-NAG activity and cumulative blood lead index $(r=0.25 ; p=0.036)$. For the other groups of lead workers and referents no significant correlations were found between U-albumin and $\mathrm{U}-\boldsymbol{\beta}_{2}-\mathrm{m}$ concentrations and U-NAG activity on the one hand and the concentrations of $\mathrm{B}-\mathrm{Pb}, \mathrm{U}-\mathrm{Pb}$, lead in calcaneus and tibia, and cumulative blood lead index on the other.

\section{Discussion}

Blood lead analyses of exposed workers have been performed at the research laboratory of the smelter since 1950. During the period January 1950 to December 1987, 81081 blood lead analyses were made in samples from 7714 workers. The surveillance programme has been focused on the lead department. Of the workers, 298 have given more than 50 blood samples each and 48 more than 200 samples. Because of these unique blood lead records, it has been possible to calculate a time integrated blood lead index for each lead smelter worker from 1950 and onwards. This index was expressed as a summation of the annual mean blood lead values for each worker. The index reflects the previous exposure to lead for each worker in a more realistic way than the variable exposure time (duration of employment). Another way of estimating the previous exposure to lead is by measurements of lead in cortical bones such as finger bone and tibia.

It is evident from the blood lead determination that the exposure to lead has decreased considerably at the smelter over the years. From 1950 to 1987 the mean blood lead concentration among lead workers decreased from $3.0 \mu \mathrm{mol} / 1$ to about $1.6 \mu \mathrm{mol} / 1$. For workers exposed to lead at other metal producing plants, the corresponding decrease was from $2 \cdot 7$ to $0.8 \mu \mathrm{mol} / 1$.

It is well known that occupational exposure to lead 
may effect renal function. ${ }^{2327} 28$ The cells lining the proximal tubules appear to be the tissue in the kidney most sensitive to lead. ${ }^{29}$ At concentrations of lead in blood of around $1.6 \mu \mathrm{mol} / 1$, lead may partially inhibit the metabolic activation of vitamin $\mathrm{D}$, a transformation that occurs in these cells. ${ }^{30}$

Two principal stages of effects of lead on the kidneys have been defined. Stage I is the period of acute effects and is limited to functional and morphological changes in proximal tubular cells. It is manifest clinically as a decrease in energy dependent transport functions, including aminoaciduria, glucosuria, and changes in specific ion transport. The functional changes are thought to be related to an effect on mitochondrial respiration and phosphorylation. The intranuclear inclusion bodies are a characteristic feature of stage I nephropathy. These occur in the cells lining the proximal tubules at blood lead concentrations of 2-4 $\mu \mathrm{mol} / 1$ and are composed of lead protein complexes. ${ }^{42}$ They are thought to serve as a protective temporary storage mechanism by which soft tissue lead is incorporated into a non diffusable form, thereby reducing the cytoplasmic concentration of lead available to disrupt essential cell function. ${ }^{5}$

Stage II is defined as a chronic irreversible condition, characterised by interstitial fibrosis, tubular atrophy, and dilatation and arteriosclerotic changes. $^{35} 3132$

Older studies of the effects of lead on kidney function have often used parameters such as concentration of blood urea nitrogen (BUN), serum (S)-creatinine, or total urinary protein concentration as measurements of renal function. Due to the great reserve capacity of the kidney, however, these measures of excretory function can be in the normal range despite considerable impairment of renal function. Blood urea nitrogen and S-creatinine concentrations will increase only when about two thirds of kidney function is lost, and are thus unlikely to detect early or moderate loss of renal function due to lead.

The excretion of low molecular weight proteins in the urine may be a sensitive indicator of early renal injury. Both $\beta_{2}-\mathrm{m}$ and retinol binding protein are freely filtered from the plasma by the renal glomerulus and are taken up by the proximal tubular cells where they are catabolised. The reabsorption of these proteins by the normal kidneys is nearly complete at $99.97 \%$ of the filtered load. Thus their concentration in urine is a sensitive index of altered proximal tubular function. ${ }^{33}$

Another sensitive indicator of renal injury, especially for the detection of possible damage to proximal tubules by lead is multiple enzyme analysis. ${ }^{34}$ Activity of $\mathrm{N}$-acetyl- $\beta$-D-glucosaminidase, a lysosomal enzyme present in the brush borders of the proximal tubular cells, has been shown to be raised in urine at the early stages of renal injury, before abnormalities in excretory function take place. ${ }^{32}$ Thus both $\mathrm{U}-\beta_{2}-\mathrm{m}$ concentration and U-NAG activity were chosen as sensitive markers of early tubular damage in our study.

The glomerulus is the main barrier to the renal elimination of high molecular weight $(>40000)$ proteins. The filtration of proteins by the glomerulus is both size and charge selective. Loss of selectivity of the glomerular filter can be detected early by measurement of the urinary excretion of high molecular weight proteins, predominantly albumin. Other larger proteins such as $\operatorname{IgG}$, IgM, and $\alpha_{2}$-macroglobulin may also show increased excretion into the urine. In this study albumin was selected as a sensitive indicator of early glomerular damage.

Chronic occupational exposure to lead resulting in concentrations of blood lead exceeding $1.9 \mu \mathrm{mol} / 1$ has been associated with subsequent renal disease. ${ }^{35}$ Other authors ${ }^{12}{ }^{36-39}$ have suggested a higher limit for kidney effects of around $3 \mu \mathrm{mol} / 1$. A large proportion of the lead workers in this study have exceeded these limits, especially during the 1950s and 1960s. Thus reversible changes in the tubular function for some workers who were active during these times could not be excluded.

Selevan et al found an excess mortality from chronic renal disease in a cohort study of 1987 men employed in a lead smelter between 1940 and $1965 .{ }^{40}$ The risk of death from renal disease increased with increasing duration of employment. In a cohort study of 4519 battery plant workers and 2300 lead production workers, a significant number of excess deaths from chronic nephritis was noted in both cohorts. ${ }^{41} 42$ The mean blood lead concentration for 1326 of the battery plant workers with three or more analyses was $3.0 \mu \mathrm{mol} / 1$, and $278 \mathrm{had}$ means of $3.4 \mu \mathrm{mol} / 1$ or more. For 537 lead production workers in four plants the mean was $3.9 \mu \mathrm{mol} / 1$. An increased mortality from chronic renal diseases has also been reported in two other cohort studies, ${ }^{4344}$ among retired lead battery workers and among lead smelter workers who had received the diagnosis of lead poisoning. In each of these four investigations, a two to threefold increase in deaths from chronic nephritis has been noted.

The smelter workers studied have had a continuous and long term exposure to lead. This is shown by a median cumulative blood lead index of $72.2 \mu \mathrm{mol} / 1$ among the retired lead workers, with corresponding median bone lead concentrations in tibia and calcaneus of 39.3 and $100 \cdot 2 \mu \mathrm{g} / \mathrm{g}$ bone mineral respectively (table 2). Despite an exposure of this magnitude, however, no signs of adverse effects on the kidney such as early tubular or glomerular damage have been found among the workers in the lead smelter. Similar results have been reported by Buchet et al. ${ }^{37}$ Bernard et al found no change in the 
urinary excretion of $\beta_{2}-\mathrm{m}$, albumin, transferrin, IgG and several enzymes in a study of 25 lead smelter workers with a mean $\mathrm{B}-\mathrm{Pb}$ concentration of $2 \cdot 1 \mu \mathrm{mol} / 1 .{ }^{45}$ Schaller et al found no increased renal excretion of proteins in workers occupationally exposed to lead $(\mathrm{B}-\mathrm{Pb}$ concentration around $2 \cdot 5-4.5$ $\mu \mathrm{mol} / 1) .{ }^{46} \mathrm{~A}$ decreased glomerular filtration rate but no increase in urinary excretion of $\beta_{2}-\mathrm{m}$ or amino acids was found among 28 workers at a lead smelter with a mean $\mathrm{B}-\mathrm{Pb}$ concentration of $3.0 \mu \mathrm{mol} / 1 .{ }^{47}$ Meyer $e t$ al found a pronounced increase in urinary excretion of NAG in a study of 29 workers with various occupations connected with exposure to lead. ${ }^{34}$ Similar findings were reported by Verschoor et al who found a slight increase in urinary excretion of NAG and retinol binding protein (RBP) with increasing $\mathrm{B}-\mathrm{Pb}$ concentrations in a study of 155 men working with lead (mean value of $\mathrm{B}-\mathrm{Pb}$ concentration $2.3 \mu \mathrm{mol} / \mathrm{l}) .^{39}$ Thus it has been suggested that U-NAG activity would be the only marker to respond at an early stage of lead nephropathy. ${ }^{48}$ Nevertheless, increased urinary excretion of NAG was not found among long term exposed lead smelter workers in our study. The lack of signs of kidney damage among the lead workers in this investigation agrees with earlier reported results from an epidemiological study of mortality from exposure to lead at the same smelter. ${ }^{22}$ In a cohort of 437 lead smelter workers, two cases of uraemia from kidney diseases that might be caused in part by exposure to lead was in agreement with the expected number of $2 \cdot 2$.

In conclusion, the extent to which low to moderate occupational exposure to lead contributes to lead nephropathy is still debated as published results have been conflicting. Available data from cohorts with long term low exposure to lead are not sufficient to make a proper judgement. Too few studies have been carried out to provide adequate information about the cumulative systemic uptake of lead with time. Because renal changes may be subtle, the number of subjects in the study population must be considered. To be able to predict excessive lead absorption and signs of early kidney damage reliably, suitable biological monitoring techniques have to be further developed and validated.

Financial support was given by the Swedish Work Environment Fund, projects no 87-0932 and 890099.

The Birmingham group has received extensive financial support from the UK Health and Safety Executive, and support for ACT from the UK Colt Foundation.

Mrs H Anundi, H Saranius, and B Åkerlund are acknowledged for the protein determinations.

Requests for reprints to: Dr L Gerhardsson, Depart- ment of Occupational and Environmental Medicine, Lund University, S-221 85 Lund, Sweden.

1 Vander AJ, Taylor DL, Kalitis K, Mouw DR, Victery W. Renal handling of lead in dogs: clearance studies. Am J Physiol 1977;233:532-8.

2 World Health Organisation. Recommended health-based limits in occupational exposure to heavy metals. Geneva: WHO, 1980. (Tech rep ser No 647.)

3 Wedeen RP. The role of lead in renal failure. Clinical and Experimental Dialysis and Apheresis 1982;6:113-46.

4 Landrigan PJ. Toxicity of lead at low dose. Br J Ind Med 1989;46:593-6.

5 Goyer RA. Lead and the kidney. Curr Top Pathol 1971;55: 147-76.

6 Batuman V, Landy E, Maesaka JK, Wedeen RP. Contribution of lead to hypertension with renal impairment. New Engl J Med 1983;309:17-21.

7 Kirkby H, Gyntelberg F. Blood pressure and other cardiovascular risk factors of long-term exposure to lead. Scand J Work Environ Health 1985;11:15-9.

8 Harlan WR, Landis JR, Schmouder RL, Goldstein NG, Harlan LC. Blood lead and blood pressure. Relationship in the adolescent and adult US population. J Am Med Assoc 1985; 253:530-4.

9 Orssaud G, Claude JR, Moreau T, Lellouch J, Juguet B, Festy B. Blood lead concentration and blood pressure. BMJ 1985; 290:244.

10 Pirkle JL, Schwartz J, Landis JR, Harlan WR. The relationship between blood lead levels and blood pressure and its cardiovascular risk implications. Am J Epidemiol 1985;121: 246-58.

11 Victery W, Vander AJ, Shulak JM, Schoeps P, Julius S. Lead, hypertension, and the renin-angiotensin system in rats. $J \mathbf{L a b}$ Clin Med 1982;99:354-62.

12 Goyer RA. Mechanisms of lead and cadmium nephrotoxicity. Toxicol Lett 1989;46:153-62.

13 Evrin PE, Wibell $L$. The serum levels and urinary excretion of $\beta_{2}$-microglobulin in apparently healthy subjects. Scand J Clin Lab Invest 1972;29:69-74.

14 Vesterberg $O$. Quantification of albumin in urine by a new method: zone immuno-electrophoresis assay (ZIA). Clin Chim Acta 1981;113:305-10.

15 Maruhn D, Fuchs I, Mues G, Bock KD. Normal limits of urinary excretion of eleven enzymes. Clin Chem 1976;22: 1567-74.

16 Westerlund-Helmerson U. Determination of lead and cadmium in blood by a modification of the Hessel method. Atomic Absorption Newsletter 1970;9:133-4.

17 Hoschek R. Parallelbestimmungen des Bleispiegels in verschiedenen Instituten. Internationales Archiv für Gewerbepathologie und Gewerbehygiene 1963;20:195-216.

18 Holmqvist I. Monitoring and control of lead health risks at a Swedish smelter. London: Lead Development Association, 1976:1-51.

19 Vahter M, ed. Assessment of human exposure to lead and cadmium through biological monitoring. Prepared for UNEP and WHO by National Swedish Institute of Environmental Medicine and Karolinska Institute (Department of Environmental Hygiene). Stockholm: 1982:1-136.

20 Friberg L, Vahter $M$. Assessment of exposure to lead and cadmium through biological monitoring. Results of a UNEP/ WHO global study. Environ Res 1983;30:95-128.

21 Wrangskog $\mathrm{K}$. Interlaboratoriekontroll avseende bestämning av bly i blod. Arbete och Hälsa (Swedish Work and Health). Stockholm: National Institute of Occupational Health 1984:15. (In Swedish.)

22 Gerhardsson $L$, Lundström N-G, Nordberg GF, Wall S. Mortality and lead exposure-a retrospective cohort study of Swedish smelter workers. Br J Ind Med 1986;43:707-12.

23 Somervaille LJ, Chettle DR, Scott MC. In vivo measurement of lead in bone using X-ray fluorescence. Phys Med Biol 1985; 30:929-43.

24 Somervaille LJ, Chettle DR, Scott MC, Aufderheide AC, Wallgren JE, Wittmers LE, et al. Comparison of two in vitro methods of bone lead analysis and the implications for in vivo measurements. Phys Med Biol 1986;31:1267-74.

25 Somervaille LJ, Chettle DR, Scott MC, Tennant DR McKiernan MJ, Skilbeck A, et al. In vivo tibia lead measurements as an index of cumulative exposure in occupationally exposed subjects. Br J Ind Med 1988;45: 174-81. 
26 Chettle DR, Scott MC, Somervaille LJ. Improvements in the precision of in vivo bone lead measurements. Phys Med Biol 1989;34:1295-300.

27 Cramer K, Goyer RA, Jagenburg R, Wilson MH. Renal ultrastructure, renal function, and parameters of lead toxicity in workers with different periods of lead exposure. $\mathrm{Br} \mathrm{J}$ Ind Med 1974;31:113-27.

28 Lilis R, Fischbein A, Eisinger J, Blumberg WE, Diamond S, Anderson HA, et al. Prevalence of lead disease among secondary lead smelter workers and biological indicators of lead exposure. Environ Res 1977;14:255-85.

29 Goyer RA, Rhyne BC. Pathological effects of lead. Int Rev Exp Pathol 1973;12:1-77.

30 Rosen JF, Chesney RW, Hamstra A, DeLuca HF, Mahaffey KR. Reduction in 1,25-dihydroxyvitamin $\mathrm{D}$ in children with increased lead absorption. N Engl J Med 1980;302:1128-31.

31 Wedeen RP, Mallik DK, Batuman V. Detection and treatment of occupational lead nephropathy. Arch Intern Med 1979;139: 53-7.

32 Bernard BP, Becker CE. Environmental lead exposure and the kidney. Clin Toxicol 1988;26:1-34.

33 Elinder CG, Edling C, Lindberg E, Kågedal B, Vesterberg O. Assessment of renal function in workers previously exposed to cadmium. Br J Ind Med 1985;42:754-60.

34 Meyer BR, Fischbein A, Rosenman K, Lerman Y, Drayer DE, Reidenberg MM. Increased urinary enzyme excretion in workers exposed to nephrotoxic chemicals. Am J Med 1984; 76:989-98.

35 Osterloh JD, Selby JV, Bernard BP, Becker CE, Menke DJ, Tepper E, et al. Body burdens of lead in hypertensive nephropathy. Arch Environ Health 1989;44:304-10.

36 Wedeen RP, Maesaka JK, Weiner B, Lipat GA, Lyons MM, Vitale LF, et al. Occupational lead nephropathy. Am J Med 1975;59:630-41.

37 Buchet JP, Roels H, Bernard A, Lauwerys R. Assessment of renal function of workers exposed to inorganic lead, cadmium or mercury vapor. J Occup Med 1980;22:741-50.
38 Lilis R, Fischbein A, Valciukas JA, Blumberg W, Selikoff IJ. Kidney function and lead: relationships in several occupational groups with different levels of exposure. Am J Ind Med 1980;1:405-12.

39 Verschoor M, Wibowo A, Herber R, van Hemmen J, Zielhuis R. Influence of occupational low-level lead exposure on renal parameters. Am J Ind Med 1987;12:341-51.

40 Selevan SG, Landrigan PJ, Stern FB, Jones JH. Mortality of lead smelter workers. Am J Epidemiol 1985;122:673-83.

41 Cooper WC, Wong $\mathrm{O}$, Kheifets $\mathrm{L}$. Mortality among employees of lead battery plants and lead-producing plants, 1947-1980. Scand J Work Environ Health 1985;11:331-45.

42 Cooper WC. Deaths from chronic renal disease in US battery and lead production workers. Environ Health Perspect 1988; 78:61-3.

43 Malcolm D, Barnett HAR. A mortality study of lead workers 1925-76. Br J Ind Med 1982;39:404-10.

44 McMichael AJ, Johnson HM. Long-term mortality profile of heavily-exposed lead smelter workers. J Occup Med 1982; 24:375-8.

45 Bernard A, Roels HA, Buchet JP, Lauwerys RR. Comparison by sodium dodecyl sulfate-polyacrylamide gel electrophoresis of urinary proteins excreted by workers exposed to cadmium, mercury or lead. Toxicol Lett 1980;5:219-22.

46 Schaller KH, Gonzales J, Thürauf J, Schiele R. Detection of early kidney damages in workers exposed to lead, mercury and cadmium. Zentralblatt für Bakteriologie, Mikrobiologie und Hygiene 1980;171:320-35.

47 Hammond PB, Lerner SI, Gartside PS, Hanenson IB, Roda SB, Foulkes EC, et al. The relationship of biological indices of lead exposure to the health status of workers in a secondary lead smelter. J Occup Med 1980;22:475-84.

48 Bernard A, Lauwerys R. Epidemiological application of early markers of nephrotoxicity. Toxicol Lett 1989;46:293-306.

Accepted 8 July 1991

\section{Correspondence and editorials}

The British Journal of Industrial Medicine welcomes correspondence relating to any of the material appearing in the journal. Results from preliminary or small scale studies may also be published in the correspondence column if this seems appropriate. Letters should be not more than $\mathbf{5 0 0}$ words in length and contain a minimum of references. Table and figures should be kept to an absolute minimum. Letters are accepted on the understanding that they may be subject to editorial revision and shortening.

The journal now also publishes editorials which are normally specially commissioned. The Editor welcomes suggestions regarding suitable topics; those wishing to submit an editorial, however, should do so only after discussion with the Editor. 